\title{
KARAKTERISTIK BAKTERI PEREDUKSI MERKURI (Escherichia coli) DIISOLASI DARI PERAIRAN PANTAI TELUK MANADO
}

\author{
Frans G. ljong dan Henny A. Dien ${ }^{1}$
}

\begin{abstract}
In the environment like seawater, mercury can be oxidized by some bacteria, such as Thiobacillus, to produce $\mathrm{Hg}$ ions which are soluble in water and toxic to marine organisms, such as bacteria, algae, and so on. On the other hand, the occurrence of Pseudomonas, as $E$. coli, is believed can reduce the number of $\mathrm{Hg}$ ions in the environment. An experiment was conducted to count total coliform and total $E$. coli, to isolate, to identify $E$. coli isolated from Manado Bay seawater, and to determine the ability of $E$. coli isolates to do reduction and or oxidation of mercury ions. Seawater samples were collected from the reclamation area, especially close to Tondano River, Sario River and Bahu River around Manado Bay. As a control, some water samples were taken from Bunaken Island waters at Liang and Muka Kampung area. An amount of $500 \mathrm{ml}$ water samples was taken from the sampling site and placed into container, then brought to the laboratory for further analysis, such as total coliform, total E. coli. In addition, some biochemical tests were also carried out in order to identify the isolate. The results showed that nearly all isolates of $E$. coli $(83.3 \%)$ exhibited their ability in mercury ions oxidation, while the isolates that can reduce ion mercury were $13.3 \%$ only. The highest $\mathrm{Hg}$-ions reduction was influenced by the characteristic of isolates, and mercury ions oxidation was also dependent upon the strain type.
\end{abstract}

Keywords: E. coli, reduction-oxidation, Hg-ions.

\begin{abstract}
ABSTRAK
Dalam lingkungan perairan laut, merkuri dapat teroksidasi oleh beberapa bakteri, seperti Thiobacillus. Bakteri ini dapat menghasilkan ion $\mathrm{Hg}$ yang larut dalam air dan bersifat racun bagi organisme laut lainnya. Di sisi lain, kehadiran Pseudomonas seperti juga E. coli, diyakini dapat mengurangi jumlah ion $\mathrm{Hg}$ di lingkungan. Tujuan penelitian ini adalah menghitung total coliform dan total E. coli, untuk mengisolasi dan mengidentifikasinya dari perairan Teluk Manado, dan menentukan kemampuan isolat $E$. coli dalam mereduksi dan mengoksidasi ion-ion merkuri. Sampel air laut dikumpulkan dari areal reklamasi, terutama di daerah yang dekat dengan Sungai Tondano, Sungai Sario dan Sungai Bahu. Sebagai kontrol, beberapa sampel air (@ 500 sampel ml) diambil dari perairan Pulau Bunaken di Liang dan Kampung Muka, kemudian dibawa ke laboratorium untuk dianalisis lebih lanjut, seperti total coliform, jumlah E. coli. Selain itu, beberapa tes biokimia juga dilakukan untuk mengidentifikasi isolat. Hasil penelitian menunjukkan bahwa hampir semua isolat $E$. coli $(83,3 \%)$ menunjukkan kemampuan mereka dalam mengoksidasi ion merkuri, sedangkan isolat yang dapat mengurangi ion merkuri hanya $13,3 \%$ saja. Penurunan ion $\mathrm{Hg}$ tertinggi dipengaruhi oleh karakteristik isolat, demikian pula dengan kemampuan oksidasi ion merkuti tergantung pada jenis strainnya.
\end{abstract}

Kata kunci: E. coli, reduksi-oksidasi $\mathrm{Hg}$, ion $\mathrm{Hg}$.

\footnotetext{
${ }^{1}$ Staf pengajar Fakultas Perikanan dan IImu Kelautan Universitas Sam Ratulangi, Manado, Sulawesi Utara
} 


\section{PENDAHULUAN}

Di alam, merkuri akan mengalami oksidasi oleh mikroba seperti oleh Thiobacillus sehingga dihasilkan ion-ion merkuri yang bersifat larut air dan racun bagi biota laut, terutama terhadap komunitas organisme mikroskopis seperti bakteri. Sebagai asumsi, apabila jumlah merkuri mengalami peningkatan maka jumlah ion-ion $\mathrm{Hg}$ yang dihasilkan dari proses biokimia oleh mikroba juga akan mengalami peningkatan. Hasil penelitian ljong (2004) melaporkan bahwa Thiobacillus dalam jumlah tertentu berpotensi dalam meningkatkan jumlah ion-ion $\mathrm{Hg}$, sehingga resiko keracunan ion-ion $\mathrm{Hg}$ terhadap biota laut akan menjadi lebih nyata. Namun, secara alamiah di perairan laut juga dapat ditemukan sejumlah bakteri lain yang mampu melakukan reduksi terhadap ion-ion $\mathrm{Hg}$ sehingga dapat mengurangi resiko keracunan. Salah satu bakteri yang dapat melakukan reduksi terhadap ion-ion $\mathrm{Hg}$ adalah Pseudomonas sp. (Brock dan Madigan, 1991). Maka akan sangat menarik apabila dilakukan penelitian terhadap bakteri ini untuk mendapatkan gambaran apakah di perairan Teluk Manado dapat ditemukan spesies-spesies Pseudomonas yang memiliki kemampuan mereduksi ion-ion $\mathrm{Hg}$ yang beresiko tersebut. Penelitian sebelumnya ljong (2005) melaporkan bahwa $E$. coli memiliki potensi sebagaimana yang diperankan oleh Pseudomonas sp. untuk mereduksi ion-ion merkuri di perairan, namun seberapa besar potensi reduksinya masih belum diketahui.

Berdasarkan asumsi-asumsi tersebut, penelitian ini difokuskan untuk mempelajari peranan bakteri $E$. coli yang diisolasi dari perairan Teluk Manado dalam mereduksi ion-ion $\mathrm{Hg}$ yang dihasilkan baik melalui mekanisme reaksi biologi maupun kimia.

\section{METODE PENELITIAN}

\section{Perhitungan Total E. coli dan Teknik Isolasinya}

Total $E$. coli dihitung dengan metode MPN menggunakan Brilliant Green Lactose Broth (BGLB) yang diikuti dengan penggoresan pada media Eosine Methylene Blue Agar. Bakteri E. coli diisolasi dengan cara dari sampel air laut, diambil sejumlah $1 \mathrm{ml}$ ditumbuhkan dalam Lactose Broth, diikuti dengan penggoresan pada EMB Agar. KoIoni yang tumbuh bebas diambil dengan jarum Ose dan dipindahkan ke dalam media agar miring, diinkubasi pada suhu $35^{\circ} \mathrm{C}$ selama 24 jam. Agar miring yang positif (tumbuh) disimpan sebagai kultur sediaan untuk tujuan identifikasi (Cappucino dan Sherman, 1992).

\section{Penetapan kondisi media kultur}

Media MT-3 dan NA (dimodifikasi) yang dikembangkan pada penelitian sebelumnya (ljong, 2004, 2005 dan 2006), diaplikasikan pada beberapa kondisi suhu $\left(30,35,40\right.$, dan $\left.45^{\circ} \mathrm{C}\right), \mathrm{pH}(5,4 ; 6,8 ; 7,4$ dan 8,0), untuk mendapatkan kondisi pertumbuhan optimal. Isolasi $E$. coli dilakukan dengan cara aseptik, isolat uji diinokulasikan ke dalam media MT-3 Broth dengan beberapa kondisi $\mathrm{pH}$. Biakan bakteri diinkubasi pada beberapa tingkat suhu selama 24 jam, kemudian kualitas pertumbuhannnya diuji dengan menggunakan spetrofotometer (Shimadzu UV VIS 160) pada panjang gelombang $660 \mathrm{~nm}$ atau dengan teknik pertumbuhan pada kuadran. Pertumbuhan yang baik didasarkan pada hasil pengukuran yang menunjukkan nilai absorbansi tertinggi dan atau tingginya pertumbuhan koloni pada setiap kuadran.

\section{Pengukuran pengaruh ion-ion logam terhadap pertumbuhan dan laju reduksi- oksidasi ion-ion merkuri oleh isolat uji}

Berdasarkan kondisi optimum yang diperoleh, selanjutnya dibuat media MT-3 Broth yang dimodifikasi dengan penambahan ion divalen $\mathrm{HgCl}_{2}$, selanjutnya isolat uji diinokulasi pada media tersebut dan kualitas pertumbuhannya diukur. Pada uji ini, $\mathrm{HgCl}_{2}(2 \mathrm{~mm})$ digunakan sebagai pembanding. Sedangkan pengaruh ion-ion logam terhadap laju reduksi dan oksidasi ion-ion merkuri oleh $E$. coli ditentukan dengan mengukur jumlah ion $\mathrm{Hg}$ dalam satu satuan milivolt (Ijong dan Suwetja, 2003).

\section{HASIL DAN PEMBAHASAN}

\section{Kondisi fisik dan kimia area sampling}

Hasil pengukuran terhadap kondisi fisik dan kimia pada lokasi penelitian secara umum, $\mathrm{pH}$ berkisar $7,98-8,31$, suhu ber- 
kisar antara $28-28,7^{\circ} \mathrm{C}$ dengan kisaran Salinitas $29-33 \%$ untuk lokasi sampling di pesisir pulau Bunaken, sedangkan untuk lokasi sampling di perairan pesisir Teluk Manado kisaran $\mathrm{pH} 8,24-8,42$, suhu $28,5-31^{\circ} \mathrm{C}$ dengan salinitas yang agak bervariasi 24$32 \%$. Rendahnya salinitas ini disebabkan karena pada lokasi muara sungai dapat disebabkan terjadi pencampuran air sungai dan air laut. Pada umumnya kondisi air laut pada saat pengambilan sampel jernih dengan profil bebatuan, kecuali untuk muara Sungai Sario airnya agak keruh.

\section{Total coliform dan Total E. coli}

Tabel 1 mendeskripsikan jumlah total coliform dan total E. coli selang waktu sampling bulan Maret sampai dengan Juni. Bervariasinya jumlah total coliform dan total E. coli selama sampling dilakukan sangat dipengaruhi oleh tingkat kontaminasi terutama yang berasal dari daratan seperti jumlah penyelam khususnya untuk pulau Bunaken serta buangan limbah domestik untuk wilayah muara sungai yang ada di pesisir Teluk Manado.

Tabel 1. Total coliform dan Total E. coli (MPN/100 ml)

\begin{tabular}{lcccccccc}
\hline \multirow{2}{*}{$\begin{array}{c}\text { Lokasi } \\
\text { Sampling }\end{array}$} & \multicolumn{2}{c}{ Maret } & \multicolumn{2}{c}{ April } & \multicolumn{2}{c}{ Mei } & \multicolumn{2}{c}{ Juni } \\
\cline { 2 - 8 } Liang & $1,8 \times 10^{3}$ & $\mathbf{B}$ & $\mathbf{A}$ & $\mathbf{B}$ & $\mathbf{A}$ & $\mathbf{B}$ & $\mathbf{A}$ & $\mathbf{B}$ \\
Bunaken & $2,2 \times 10^{3}$ & $9,0 \times 10$ & $9,0 \times 10$ & 0 & $9,0 \times 10^{2}$ & 10 & $2,4 \times 10^{3}$ & $9,0 \times 10^{2}$ \\
S. Tondano & $1,1 \times 10^{5}$ & $1,1 \times 10^{2}$ & $2,4 \times 10^{5}$ & $1,8 \times 10^{3}$ & $2,4 \times 10^{4}$ & $1,1 \times 10^{2}$ & $1,1 \times 10^{6}$ & $2,3 \times 10^{3}$ \\
S. Sario & $1,1 \times 10^{5}$ & $1,5 \times 10^{3}$ & $1,1 \times 10^{6}$ & $2,1 \times 10^{3}$ & $1,1 \times 10^{6}$ & $2,1 \times 10^{3}$ & $1,1 \times 10^{6}$ & $9,3 \times 10^{3}$ \\
S. Bahu & $1,1 \times 10^{5}$ & $2,8 \times 10^{4}$ & $4,6 \times 10^{5}$ & $2,8 \times 10^{3}$ & $4,3 \times 10^{4}$ & $9,3 \times 10^{2}$ & $1,1 \times 10^{6}$ & $1,5 \times 10^{3}$ \\
Kontrol & - & - & - & - & - & - & - & - \\
\hline Ket.: & (A) Coliform; (B) E. Coli; (S) Sungai; & & \\
& (-) negatif/tidak tumbuh; $n=>2$ & & &
\end{tabular}

Total coliform dan total E. coli untuk lokasi sampling Pulau Bunaken relatif lebih rendah dibandingkan dengan lokasi sampling di muara sungai yang ada di pesisir Teluk Manado. Hal ini mengindikasikan bahwa tingkat kontaminasi yang disumbangkan melalui sungai-sungai tersebut cukup tinggi sehingga perlu menjadi bahan pertimbangan pemangku kepentingan (pemerintah, lembaga-lembaga terkait dan masyarakat) dalam rangka menata ekosistem daerah aliran sungai serta sistem drainase dan tata kelola septiktank yang ada di sepanjang daerah aliran sungai tersebut. Ketiga sungai yang bermuara di Teluk Manado (Sungai Tondano, Sario dan Bahu) memiliki kisaran total coliform antara
$2,4 \times 10^{4}-1,1 \times 10^{6} \mathrm{MPN} / 100 \mathrm{ml}$, nilai terendah diperoleh pada sungai Tondano $\left(1,1 \times 10^{2}\right.$ MPN/100 ml), sedangkan nilai tertinggi diperoleh pada sungai Bahu waktu sampling bulan Maret $\left(1,1 \times 10^{4} \mathrm{MPN} / 100 \mathrm{ml}\right)$. Secara keseluruhan nilai tertinggi total coliform dan E. coli diperoleh pada Maret dan Juni, sedangkan nilai terendah pada bulau Mei.

Tingginya kontaminasi kelompok bakteri coliform secara khusus $E$. coli yang disumbangkan melalui kontaminasi sungaisungai yang bermuara di perairan Teluk Manado memberikan resiko secara langsung terhadap kualitas/mutu perairan pantai teluk Manado yang sangat berpotensi sebagai daerah wisata bahari. Bahkan lebih lanjut dari hasil penelitian sebelumnya ljong (2006) menemukan bahwa beberapa strain bakteri Gram negatif batang seperti Pseudomonas sp. memiliki potensi menurunkan derajat toksisitas ion merkuri di alam termasuk di perairan Teluk Manado karena kemampuannya melakukan reduksi terhadap ion logam berat tersebut. Hasil penelitian tersebut menyimpulkan bahwa semakin tinggi jumlah kontaminan bakteri Gram negatif batang seperti Pseudomonas di perairan maka resiko peningkatan toksisitas ion merkuri akan dapat ditekan.

\section{Karakteristik biokimia isolat $E$. coli}

Tabel 2 mendeskripsikan karakteristik biokimia isolat uji yang diisolasi dari air laut di Teluk Manado. Isolat yang dipilih berjumlah 30 isolat yang semuanya bersifat Gram-negatif batang dengan bentuk sel batang, batang pendek dan kokobasili. Pada umumnya isolat uji memfermentasi laktosa dan menghasilkan asam dan gas, indol dan metil red positif, oksidase negatif, tidak menggunakan sitrat sebagai sumber energi dan motil, sedangkan uji lainnya memberikan hasil yang bervariasi. Menurut Sneath at al. (1982), E. coli memiliki karakteristik memfermentasi laktosa menghasilkan asam dan gas, oksidase negatif, indol dan methyl red positif. Selanjutnya dinyatakan oleh Cappucinno dan Sherman (1992) bahwa ciri-ciri yang membedakannya dengan anggota famili Enterobactericeae yang lain yaitu melalui uji IMVIC (indol-methyl red-voges proskauer-citrate), karena memberi respon ++-- pada setiap uji tersebut. 
Tabel 2. Hasil Pengujian Biokimia isolat E. coli diisolasi dari perairan pantai Manado.

\begin{tabular}{|c|c|c|c|c|c|c|c|c|c|c|c|c|c|c|}
\hline \multirow{3}{*}{ Isolat } & \multicolumn{2}{|c|}{$\begin{array}{l}\text { Karakteristik } \\
\text { Mikroskopis }\end{array}$} & \multicolumn{5}{|c|}{ Fermentasi } & \multirow{3}{*}{ 흠 } & \multirow{3}{*}{ 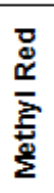 } & \multirow{3}{*}{ 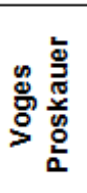 } & \multirow{3}{*}{$\begin{array}{l}\text { 苋 } \\
\text { 売 }\end{array}$} & \multirow{3}{*}{ 昙 } & \multirow{3}{*}{ 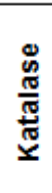 } & \multirow{3}{*}{ 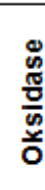 } \\
\hline & \multirow{2}{*}{ Gram } & \multirow{2}{*}{ Bentuk } & \multicolumn{2}{|c|}{ Glu } & Lak & \multicolumn{2}{|c|}{ Suk } & & & & & & & \\
\hline & & & $A$ & G $A$ & G & A & G & & & & & & & \\
\hline B2 & - & SR & + & + & + & + & + & + & + & - & - & + & + & - \\
\hline BKN30 & - & SR & + & + & + & + & + & + & + & - & - & + & - & - \\
\hline B33 & - & $\mathrm{R}$ & + & + & + & + & + & + & + & - & W & + & + & - \\
\hline $\mathrm{S} 30$ & - & $\mathrm{R}$ & + & + & + & + & + & + & + & - & - & + & + & - \\
\hline B11 & - & $\mathrm{R}$ & + & - & + & + & - & + & + & - & - & + & - & - \\
\hline BKN20 & - & $\mathrm{R}$ & + & + & + & + & - & + & + & - & - & + & + & - \\
\hline S31 & - & CB & + & + & + & + & + & + & + & - & - & + & + & - \\
\hline S32 & - & SR & + & - & + & + & - & + & + & - & - & + & + & - \\
\hline T21 & - & CB & + & $+\quad+$ & + & - & - & + & + & - & - & + & + & - \\
\hline T12 & - & CB & + & $++b$ & + & + & + & + & + & - & W & + & + & - \\
\hline T30 & - & $\mathrm{R}$ & - & $-+b$ & + & - & - & + & + & - & - & $+/-$ & - & - \\
\hline B22 & - & $\mathrm{R}$ & - & $-+b$ & + & - & - & + & + & - & - & $+/-$ & + & - \\
\hline S 33 & - & SR & + & $+\quad+$ & + & + & + & + & + & - & - & + & + & - \\
\hline $\mathrm{T} 21$ & - & SR & + & + & + & - & - & + & + & - & - & + & + & - \\
\hline $\mathrm{S} 13$ & - & $\mathrm{R}$ & - & + & + & - & - & + & + & - & - & + & + & - \\
\hline S22 & - & SR & - & + & + & - & - & + & + & - & - & + & + & - \\
\hline B22 & - & CB & + & + & + & + & + & + & + & - & - & + & + & - \\
\hline T10 & - & CB & + & + & + & + & + & + & + & W & - & + & + & - \\
\hline L30 & - & SR & + & + & + & + & + & + & + & - & - & + & + & - \\
\hline B12 & - & $\mathrm{R}$ & + & + & + & + & - & + & + & - & - & + & + & - \\
\hline B13 & - & $\mathrm{R}$ & - & + & + & - & - & + & + & - & - & + & + & - \\
\hline T32 & - & SR & + & + & + & + & - & + & + & - & - & + & + & - \\
\hline T33 & - & SR & V & + & + & & & + & + & - & - & + & + & - \\
\hline L21 & - & $\mathrm{R}$ & - & + & + & - & - & + & + & - & - & + & - & - \\
\hline B30 & - & $\mathrm{R}$ & + & + & + & - & - & + & + & - & - & + & + & - \\
\hline BKN30 & - & $\mathrm{R}$ & + & + & + & + & + & + & + & - & - & + & + & - \\
\hline L33 & - & CB & + & + & + & + & + & + & + & - & - & + & + & - \\
\hline T31 & - & CB & + & + & + & + & + & + & + & - & - & + & + & - \\
\hline B31 & - & $\mathrm{R}$ & + & + & + & - & - & + & + & - & - & + & + & - \\
\hline B33 & - & CB & + & $+\quad+$ & + & + & - & + & + & - & - & + & + & - \\
\hline
\end{tabular}

Ket.: Glu (Glukosa), Lak (laktosa), Suk (sukrosa), SR (short rod), R (rod), CB (cocobacilli), - (negatif), + (positif), w (weak) +/- (variatif).

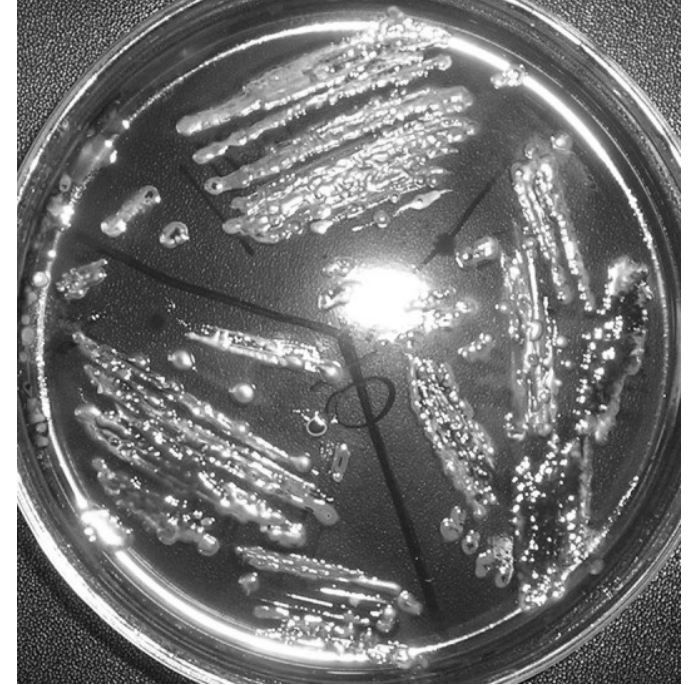

Gambar 1. Tipikal koloni isolat E. coli. pada media EMB Agar.

Sifat koloni isolat $E$. coli yang diisolasi dari perairan pantai Teluk Manado (Gambar 1), memiliki karakteristik koloni berbentuk regular dengan permukaan agak cembung, berwarna hijau metalik pada permukaan media eosin methylene blue (EMB) agar. Karakteristik koloni E. coli yang tumbuh pada media EMB agar, biasanya berwarna merah metalik atau hijau metalik, berbeda dengan famili Enterobactericeae lainnya seperti Salmonella dan Proteus jika tumbuh pada media ini akan menampakan koloni yang berwarna merah muda tanpa disertai karakteristik metalik pada permukaan koloninya (Atlas, 1993).

\section{Potensi Reduksi dan oksidasi isolat $E$. coli}

Hasil pengukuran tingkat reduksi dan oksidasi terhadap isolat uji (Tabel 3), menunjukkan bahwa sebagian besar isolat uji E. coli $(83,3 \%)$ berpotensi melakukan oksidasi terhadap ion merkuri dan hanya sebagian kecil $(13,3 \%)$ yang memiliki kemampuan melakukan reduksi terhadap ion merkuri, bahkan ada isolat yang tidak 
melakukan baik oksidasi maupun reduksi $(0,3 \%)$. Hasil penelitian ini sekaligus memberikan jawaban terhadap pertanyaan yang timbul pada penelitian-penelitian sebelumnya tentang "apakah semua bakteri Gram negatif batang berpotensi mereduksi ion merkuri". Isolat E. coli yang diisolasi dari perairan pantai Teluk Manado memiliki kemampuan melakukan reduksi terhadap $\mathrm{Hg}$, walaupun demikian ada juga yang berperan sebaliknya yaitu potensil melakukan oksidasi terhadap $\mathrm{Hg}$. Hasil penelitian memperkuat temuan pada penelitian sebelumnya ljong (2004) dan ljong (2005) yang menyimpulkan bahwa bakteri Gram-negatif batang memiliki kemampuan melakukan oksidasi dan reduksi terhadap ion merkuri.

Hasil analisis menunjukkan bahwa tingginya presentase isolat $E$. coli yang diisolasi dari perairan pantai Teluk Manado yang memiliki kemampuan mengoksidasi ion merkuri dibanding dengan yang memiliki kemampuan mereduksi ion merkuri mempertegas akan bahaya bakteri ini, bukan hanya sebagai patogen yang dapat menyebabkan penyakit melalui mengkonsumsi hasil laut yang terkontaminasi olehnya, tetapi di sisi lain juga sangat potensil meningkatkan derajat toksisitas perairan sebagai akibat dari teroksidasinya ion-ion merkuri oleh E. coli. Kemampuan mengoksidasi bahkan mereduksi ion-ion merkuri di perairan laut oleh isolat $E$. coli dapat mengindikasikan juga bahwa sistem transportasi ionion logam melalui dinding selnya telah mengalami perubahan bahkan diduga hal ini kemudian akan berpengaruh terhadap sifat ketahanannya terhadap antibiotik ketika terjadi outbreak karena mengkonsumsi hasil perikanan yang terkontaminasi bakteri tersebut.

Data yang ada jelas menunjukkan bahwa meningkatnya jumlah $E$. coli di perairan pantai Teluk Manado dapat menyebabkan kerugian terhadap pengembangan ekowisata bahari, sebab selain jumlah bakteri ini dipersyaratkan sebagai acuan kualitas suatu perairan untuk objek wisata, juga disisi lain bakteri ini memberi andil terhadap peningkatan toksisitas ion-ion merkuri. Walaupun kemampuan mengkosidasi ionion merkuri $E$. coli masih jauh di bawah kemampuan bakteri Thiobacillus sp. (ljong, 2004), tetapi hasil penelitian ini memberi peringatan bahwa diperlukan upaya untuk mengontrol meningkatnya jumlah $E$. coli di perairan pantai Teluk Manado, melalui beberapa upaya konstruktif seperti meminimalisasi buangan limbah domestik, menata sistem septiktank di sepanjang daerah aliran sungai, menata sistem drainase kota melalui water treatmen system.

Tabel 3. Potensi Reduksi/oksidasi merkuri oleh isolat E. coli

\begin{tabular}{lllr}
\hline $\begin{array}{c}\text { Nomor } \\
\text { Isolat }\end{array}$ & pH & Mv & $\begin{array}{r}\text { \%Reduksi } \\
\text { loksidasi }\end{array}$ \\
\hline B2 & 3,23 & 222,4 & 7,868 \\
BKN30 & 3,25 & 221,2 & 7,368 \\
B33 & 3,31 & 217,4 & 5,749 \\
S30 & 3,31 & 218,2 & 6,095 \\
B11 & 3,33 & 216,9 & 5,532 \\
BKN20 & 3,34 & 216,0 & 5,138 \\
S31 & 3,36 & 214,8 & 4,608 \\
S32 & 3,35 & 215,3 & 4,830 \\
T21 & 3,34 & 214,7 & 4,564 \\
T12 & 3,37 & 214,2 & 4,341 \\
T30 & 3,39 & 213,0 & 3,802 \\
B22 & 3,47 & 208,4 & 1,679 \\
S33 & 3,40 & 212,7 & 3,667 \\
T21 & 3,39 & 213,0 & 3,802 \\
S13 & 3,48 & 203,6 & $-0,638$ \\
S22 & 3,46 & 209,0 & 1,961 \\
B22 & 3,43 & 211,0 & 2,890 \\
T10 & 3,53 & 205,3 & 0,194 \\
L30 & 3,55 & 204,0 & $-0,441$ \\
B12 & 3,51 & 206,3 & 0,678 \\
B13 & 3,53 & 204,9 & 0 \\
T32 & 3,48 & 208,0 & 1,490 \\
T33 & 3,46 & 209,0 & 1,961 \\
L21 & 3,47 & 208,5 & 1,726 \\
B30 & 3,64 & 198,0 & $-3,484$ \\
BKN30 & 3,50 & 206,7 & 0,870 \\
L33 & 3,49 & 207,5 & 1,253 \\
T31 & 3,46 & 205,7 & 0,388 \\
B31 & 3,51 & 206,4 & 0,726 \\
B33 & 3,54 & 204,2 & $-0,342$ \\
K & 3,53 & 204,9 & 1,000 \\
\hline
\end{tabular}

Hasil pengukuran kemampuan mereduksi ion merkuri oleh isolat $E$. coli yang diisolasi dari perairan laut Teluk Manado, berhasil memperoleh beberapa isolat seperti S13, L30, B30 dan B33. Hasil tersebut menunjukkan bahwa isolat B30 memiliki kemampuan mereduksi ion-ion $\mathrm{Hg}$ lebih baik dibanding dengan isolat lainnya. Brock \& Madigan (1991) menyatakan bahwa kemampuan mereduksi atau mengoksidasi 
ion-ion logam termasuk ion-ion merkuri sangat bervariasi tergantung dari spesies bakteri, bahkan hasil penelitian ljong (2004) dan ljong (2006) terhadap isolat Thiobacillus sp. dan Pseudomonas sp. yang diisolasi dari area reklamasi pantai Manado mendapatkan hasil bervariasi. Hasil penelitian terhadap isolat $E$. coli pun memberikan penegasan yang sama.

\section{KESIMPULAN}

Isolat $E$. coli yang diisolasi dari perairan Teluk Manado bersifat Gram-negatif batang, pada umumnya bersifat kemoorganotrof. Sebagian besar $(83,3 \%)$ memiliki kemampuan mengoksidasi ion merkuri dan yang memiliki kemampuan mereduksi ion merkuri hanya $13,3 \%$. Kecenderungan kemampuan melakukan oksidasi terhadap ion merkuri oleh $E$. coli yang diisolasi dari perairan laut Teluk berpotensi meningkatkan toksisitas merkuri di perairan Teluk Manado. Kecepatan oksidasi/reduksi terhadap ion merkuri sangat bergantung pada tipe isolatnya, sehingga masih perlu diteliti lagi tentang pengaruh logam-logam lain terhadap pertumbuhan maupun laju reduksi/ oksidasi E. coli.

\section{DAFTAR PUSTAKA}

Atlas, R.M., 1993. Handbook of Microbiological Media. CRC. Press Inc., New York.

Brock, T.D., dan M.T., Madigan, 1991. Biology of Microorganism. Prentice Hall, Inc., New Jersey.
Cappucino, J.G., dan N. Sherman, 1992. Microbiology, A Laboratory Manual. The Benyamins/Cummings Publishing Co., Inc., New York.

ljong, F.G., 2004, Laju Oksidasi Merkuri Oleh Thibacillus Diisolasi Dari Perairan Pantai Teluk Manado. Laporan Akhir Penelitian Dasar, Dibiayai oleh Proyek Penelitian IImu Pengetahuan Dasar, DitJen DIKTI.

2005. Karakteristik bakteri pengokasidasi merkuri Thiobacillus Diisolasi Dari Perairan Pantai Teluk Manado. Laporan Akhir Penelitian Dasar, Dibiayai oleh Proyek Penelitian IImu Pengetahuan Dasar, Ditjen DIKTI.

\section{Karakteristik bakteri}

pereduksi merkuri (Pseudomonas sp.) diisolasi dari perairan pantai Teluk Manado. Laporan Akhir Penelitian Dasar, Dibiayai oleh Proyek Penelitian IImu Pengetahuan Dasar, DitJen DIKTI.

ljong, F. G. dan I. K. Suwetja. 2003. Kandungan merkuri pada Ikan yang ditangkap di teluk buyat. Laporan penelitian. Dibiayai oleh DIPA UNSRAT.

Sneath, P.H.A., Mair, N. S., Sharpe, M.E., and Holt, J.G. (1986). Bergey's Manual of Systematic Bacteriology. Vol. 2. Williams and Wilkins, Baltimore, USA. 